\title{
19. Unpacking the Testimony of Gerald Blitner: Cross-cultural brokerage and the Arnhem Land Expedition
}

\author{
Martin Thomas
}

The story begins at Umbakumba on the east coast of Groote Eylandt, the first base for the 1948 American-Australian Scientific Expedition to Arnhem Land. The party arrived there early in April 1948 and stayed three months. The position in the modern atlas of Umbakumba-an Aboriginal camping place for millennia-dates from the 1930s when it became a refuelling base for the Qantas Empire Airways flying boats that travelled the long-haul route between Sydney, Singapore and the south of England. Since World War II, Umbakumba had grown and morphed to the extent that officials in Darwin had come to cautiously recognise it as an Aboriginal settlement, intended in some indeterminate way for the betterment of the local population. Elsewhere in the Gulf of Carpentaria, Christian missionaries had been entrusted as the agents of this 'civilising' process. Umbakumba, in contrast, was effectively the initiative of a solitary individual: a self-styled superintendent named Frederick Harold Gray, who is said to have developed the settlement 'in protest of missionary methods'. ${ }^{1}$ Gray had no religious agenda or affiliation, and there was no place of worship, at least in the Christian sense. The Expedition botanist, Raymond Specht, has described it as a 'secular mission'. ${ }^{2}$

Within days of getting there, the Australian Museum anthropologist, Frederick McCarthy, was expressing frustration and disappointment in his diary: 'I went to bed at $9 \mathrm{pm}$. Though tired out, couldn't sleep because of our situation. Here we are, 16 of us, backed by U.S. \& Australian funds, but the natives are almost completely civilized, speaking English well and have dropped their ceremonial and hunting life.'3

The notion that Arnhem Land was a mysterious and pristine heartland - an Aboriginal enclave unpolluted by modernity — was not singular to McCarthy.

\footnotetext{
1 Rose, F. 1968, Australia Revisited: The Aborigine story from Stone Age to space age, Seven Seas Publishers, Berlin, p. 133.

2 Raymond Specht interviewed by Sally K. May and Martin Thomas, 2-4 May 2006, St Lucia, Queensland, Oral History Collection, ORAL TRC 5662, National Library of Australia (hereafter NLA), Canberra.

3 Frederick D. McCarthy, 1948, Diary 1: Groote Id, Papers of Frederick David McCarthy, Entry for 4 April 1948, MS 3513/14/1, Australian Institute of Aboriginal and Torres Strait Islander Studies (hereafter AIATSIS), Canberra.
} 
It was one of the collective fantasies that gave rise to the 1948 Expedition. ${ }^{4}$ As a newspaper of the period explained, the 'natives in Arnhem Land are particularly interesting to the American scientists as they have never developed beyond the Stone Age'. ${ }^{5}$

As much as the Expedition was constructed and promoted as a quest to discover antiquity, it is better thought of as a symptom of modernity. We see it in the Expedition photographs where Aboriginal performers have their voices recorded or watch with fascination as the visiting scientists go about their work, busy at the technological forefront. That juxtaposition of new ways and old ways is a formula repeated in image after image. This was the Expedition's comfort zone, the way it habitually declared its raison d'être - as is not surprising. The tradition of defining modernity by staging an encounter with a supposed antiquity is as old as modernity itself. ${ }^{6}$ The Expedition properly began when it arrived at Umbakumba, expecting some fossil society where men (as they called people) lived in a state of nature. Instead, they found something considerably more complex: a dynamic community, which, although geographically isolated, was by no means quarantined from historical influences.

Umbakumba was the place where the Expedition met with Gerald, or Gerry, Blitner, whom I interviewed at his home in Darwin in 2007. I was referred to him by archaeologist Sally May, who met with him some weeks earlier and heard about his role in guiding the Expedition on Groote Eylandt. Sally and I had already worked together interviewing the two surviving Expedition members (botanist, Raymond Specht, and cine-photographer, Peter Bassett-Smith) for the National Library of Australia Oral History Collection. I was in Darwin shortly after Sally's initial meeting with Gerry and she suggested that I try to set up a formal interview, to be archived by the National Library. Although her excitement was infectious, I tried hard to suppress mine. It sounded too good to be true. A year earlier I had gone to the Expedition's three main bases to see what memories remained of its visit. While a few elders dimly recalled it, they had all been children at the time and no-one could offer substantial testimony. When making inquiries about events six decades earlier, one is confronted with the brutal reality of Aboriginal life expectancy. So few people survive into their seventies, let alone their eighties or beyond. It seemed that everyone who worked closely with the Expedition had passed away.

4 Charles P. Mountford's original grant application to the National Geographic Society described the Aboriginal population as largely uninfluenced 'by white civilization'. See his Application to Chairman of the Research Committee, National Geographic Society, 5 March 1945, AASEAL Correspondence Volume 2 (1945-1948) - Applications, PRG 1218/17/5, Mountford-Sheard Collection, State Library of South Australia (hereafter SLSA), Adelaide.

5 'Arnhem land expedition plans', Northern Standard, 12 March 1948.

6 The relationship between modernity and traditional cultures is the subject of an extensive literature. Examples include Muecke, S. 2004, Ancient and Modern: Time, culture and Indigenous philosophy, UNSW Press, Sydney; and Latour, B. 1993, We Have Never Been Modern, Harvard University Press, Cambridge, Mass. 


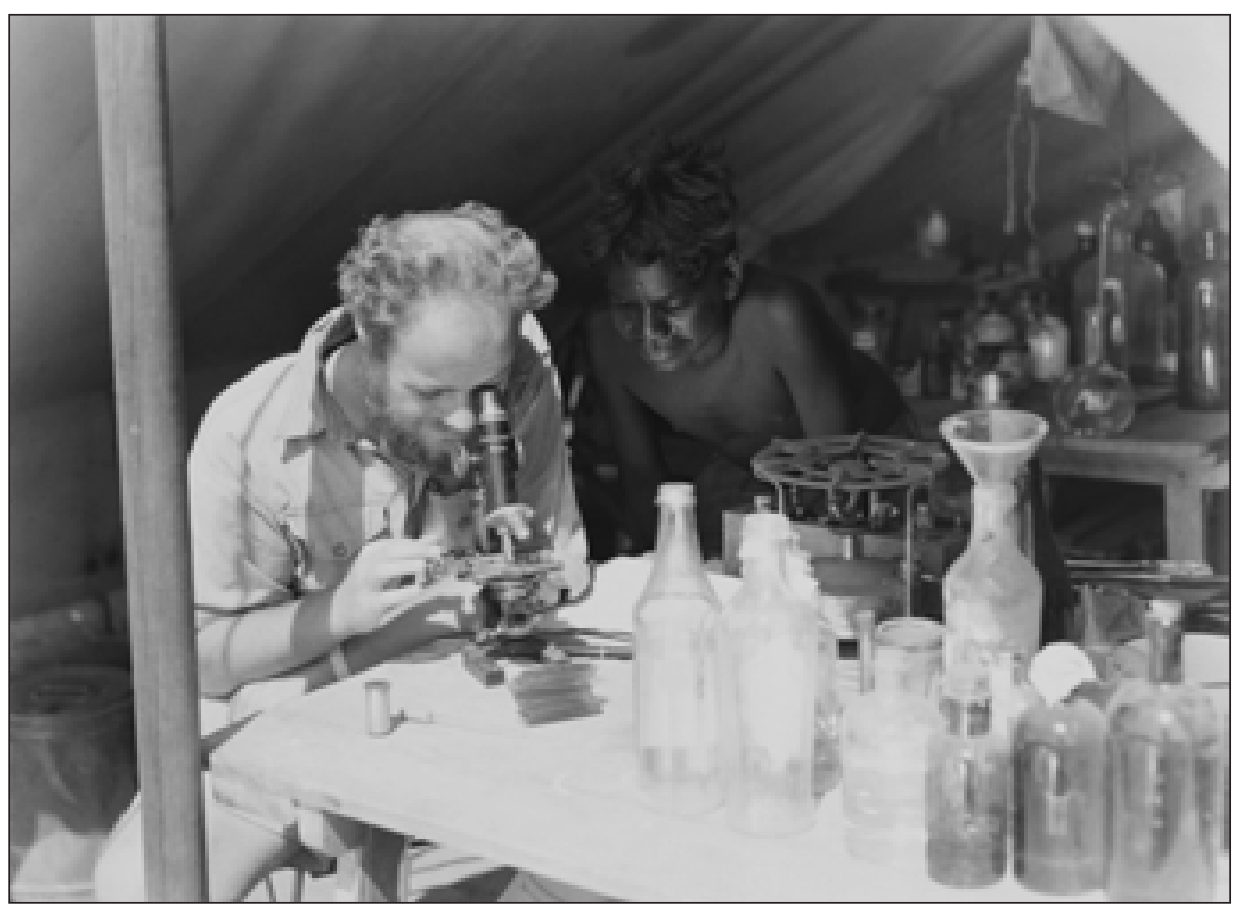

\section{Figure 19.1 Brian Billington using a microscope, watched by an unidentified boy, 1948}

Photograph by Howell Walker. By permission of National Geographic Stock.

When I phoned Gerald Blitner, I was astonished when he told me his age. Born in 1920, he was twenty-eight when the Expedition came through-certainly no child. I was struck immediately by the commanding presence of this eightyseven-year-old, even on the telephone. Although his health was poor and spells in hospital had been a troubling feature of his recent past, Gerald Blitner was still a captivating raconteur, deep-voiced and much prone to laughter. He asked me what I wanted to do with the recording and I told him that it would go to Canberra so that anyone could hear his story, told in his own words. He was checking me out, as was only appropriate. And I suppose I was checking him out too, trying to get a sense of where this might lead. He said that I could come round the next day and have a talk about it, signing off with a tantalising comment about the Expedition leader: 'And wait until you hear what I've got to say about Mr Mountford!'

After initial discussion and preparations, we began recording. Even after two days of interview - both exhaustive and exhausting - Gerry had more to say. He invited me back and we recorded for a third day a few weeks later. Since the recording is by far the most substantial commentary on the workings of the Expedition from someone of Aboriginal ancestry, the first objective of this 
chapter is to give some account of his testimony. In so doing, however, I hope to go somewhat further than simply reporting on Gerald Blitner's impressions, valuable (and at times provocative) as they are. In the first instance, I want to encourage a sympathetic hearing of Gerry's testimony; in the second, I want to facilitate a reading of it that will put it in dialogue with the larger body of evidence thrown up by the Arnhem Land Expedition. This body of evidence is truly an extensive dossier, remarkable for its plurality of perspectives and mixture of media. It is evidence that includes the diaries, notes and letters of Expedition members and associates; the 2000 pages of official reports; the vast cache of filmic, audio and photographic records; the collections of flora, fauna and objects of ethnological interest; as well as all that bureaucratic detritus, ranging from the texts of telegrams to financial paperwork. By setting the Blitner testimony in conversation with other sorts of records, it is possible to perform what I think of as a stereophonic audit of the Expedition's stay on Groote Eylandt. While keeping ears open to Gerry's story as it emerged in the process of interview, I will pick a somewhat haptic path through other evidence, evaluating how Gerry was mentioned or depicted-and scrutinising the very revealing ways in which he was overlooked or ignored.

The benefit of doing this is that it gets us closer to the messy business of cross-cultural interaction. Through this process, it becomes a little easier to think of the Expedition from multiple perspectives. Most noticeably, the early circumstances of Blitner's life - which inevitably shaped his particular slant on the Expedition story - dramatically expose the subject of race as one of the defining fault lines in the history of this research venture. The ways in which race and racism shaped his own destiny and self-image provide a compelling entree to the chequered history of Groote Eylandt in the twentieth century, so divergent from the cliché of a 'Stone-Age' culture expected by McCarthy and Mountford. By monitoring the friction that resulted from that glaring disparity between expectation and reality, we can scrutinise the pervasiveness of racial doctrines of the period.

Gerald Blitner's testimony does of course represent a subjective interpretation of the events it deals with - a caveat that must be attached to all historical evidence, whether it takes the form of written document, photograph, film or whatever. The crucial point is that his memories were substantial and that they were largely unmediated by published accounts of the Expedition, with which he seemed to be wholly unfamiliar. In the early stages of the interview, completely without prompting, he recalled the Expedition's arrival at Umbakumba and identified the roles of several personnel:

Soon as the party all landed, we had all the tents up and all the water system up there with pipes, you know, running it along there, make it easier for them, and they started and, boy, the biggest humbug, you 
know, big, big things to do. And Howell Walker wanted all the shots he could get and Frank Setzler, he wanted all the bones that he could find and all the Macassan heads that he could see, and Miller wanted every fish that he could see and an illustration about them and PC [sic] Mountford, I thought - I was told - by a couple of the people he was a self-proclaimed anthropologist and he acted that way...A tyrant, you know. He wanted it all his way, his way, his way. ${ }^{7}$

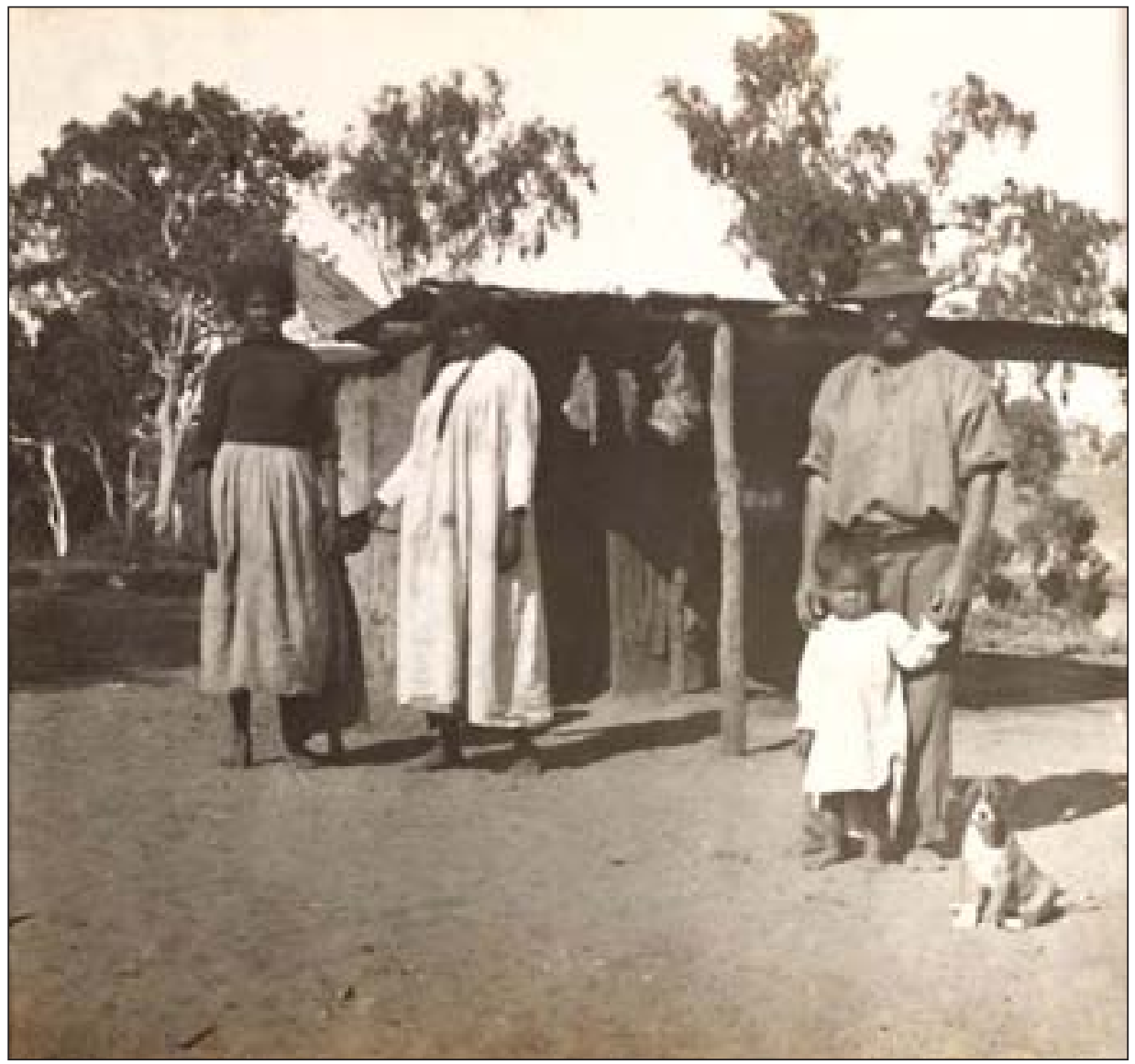

Figure 19.2 Frederick Blitner with Sarah, his second wife (name unknown), and their children Fred and Margaret (elder siblings of Gerald), 1919

Photograph attributed to C. E. Latham. By permission of Mitchell Library, State Library of New South Wales. PXA 1159, No. 44.

Even these few words reveal a nuts-and-bolts knowledge of the Expedition. Gerry's involvement, as he explained it, included guiding, translating and

7 Gerald Blitner interviewed by Martin Thomas, 27-28 August and 20 September 2007, Darwin, Oral History Collection, ORAL TRC 5851, NLA. Further Blitner quotes are from this source unless otherwise stated. 
many other duties. He was already an accomplished navigator, and on many occasions he skippered Gray's boat, the Wanderer, ferrying the researchers. At nearly 2500 sq km, Groote (meaning 'great' in Dutch) Eylandt is the largest in an archipelago of mainly small islands and reefs. Bickerton Island, situated southeast of Blue Mud Bay and west of Groote, is the second largest, and sufficiently close to the continental mainland to allow a 'hop' between coast and islands. For centuries, people have been making this journey by canoe. The anthropologist Peter Worsley, who conducted fieldwork on Groote from 1952 to 1953, put the postwar population of the island at $450 .{ }^{8}$ When Mountford and his colleagues were there, they conducted research on Groote and on several of the smaller islands. They were usually transported by Fred Gray or Gerry Blitner.

Gerry developed his sailing skills during his upbringing on the Church Missionary Society (CMS) mission, some $50 \mathrm{~km}$ from Umbakumba on the west coast of Groote. He was not originally an islander, but was born somewhere near the mouth of the Roper River on the Australian mainland. His mother, whom he knew only as Sarah, was an Aboriginal woman from the Vandalin Islands. With Gerry and her two older children, Margaret and Fred, she ended up at Roper River Mission (now Ngukurr), established in 1908 and also a CMS institution. The father of Gerry and his older siblings was Fred or Freddy Blitner, a white man involved in the trepang trade who Gerry said was of German background. He lived near Borroloola with Sarah and the children. ${ }^{9}$ If the caption of a photograph of him dated 1919 is correct, Fred Blitner cohabited with both Sarah and a second Aboriginal wife. This was never mentioned in the interview. Shortly after Gerry's birth, Freddy Blitner abandoned the family and left the region. Gerry lived with his mother and siblings at Ngukurr until the age of four. It was then that the missionaries separated him from his mother and took him to the mission on Groote - at the time situated on Emerald River (though it had moved north to Anguguru, also on the west coast of the island, by the time of the Expedition). The CMS mission on Groote was conceived from the outset as an institution for the accommodation and upbringing of so-called half-caste children whom it was thought appropriate to protect from the 'degradation of the blacks' camps'.$^{10}$ Gerry had a mission upbringing, learnt to read and write in English, worshipped as a Christian, and acquired a large range of practical skills, ranging from spear fishing to sailing. He also formed connections with the

8 Cited in Rose, F. 1960, Classification of Kin, Age Structure and Marriage Amongst the Groote Eylandt Aborigines: A study in method and a theory of Australian kinship, Deutsche Akademie der Wissenschaften zu Berlin, Berlin, p. 12.

9 Freddy Blitner, also known as 'Freshwater Admiral', was a figure of some notoriety in the Gulf Country. A thumbnail sketch appears in Jose, N. 2002, Black Sheep: Journey to Borroloola, Hardie Grant Books, South Yarra, Vic., p. 35. Harney described an encounter with him in Harney, W. 1980, Life Among the Aborigines, Rigby, Adelaide, pp. 154-5.

10 Cited in Cole, K. 1984, Fred Gray of Umbakumba: The story of Frederick Harold Gray, the founder of the Umbakumba Aboriginal settlement on Groote Eylandt, Keith Cole Publications, Bendigo, Vic., p. 35. 
Aboriginal people who lived near the mission. He learned about their culture and became fluent in Anindilyakwa, the language native to Groote. He was equally proficient in Kriol, which allowed him to communicate with Aboriginal people from other parts of Arnhem Land. ${ }^{11}$ As the years passed, Gerry was incorporated into the local classificatory kinship system and acquired the host of adoptive 'fathers', 'mothers', 'brothers' and 'sisters' whom he referred to in the interview. Perhaps this helps explain his apparent success in navigating the trauma of separation from his birth parents so early in life.

Gerald Blitner was the 'Jerry' mentioned by Smithsonian Institution anthropologist, Frank Setzler, when he described their arrival at Umbakumba by Catalina. In his diary, Setzler wrote of Fred Gray's boat coming to meet them, towing a dinghy 'made by Jerry, a half-caste and Grays [sic] right hand man'. ${ }^{12}$ Mountford's first mention of him occurred two days later, on 7 April, when 'Jerry the half-caste' ventured the opinion that the rock art on Groote had been painted not by the original Groote Islanders but by more recent arrivals from the mainland. Mountford wrote bluntly: 'Jerry's information totally unreliable.' ${ }^{\prime 3}$ Some days later, however, he had risen slightly in Mountford's opinion. 'Jerry, the half-caste' gave 'some interesting information about burials' . But Mountford remained cautious because Gerry seemed to hold 'the Groote Eylandters in poor regard'. ${ }^{14}$ When Gerry won a mention in the Expedition diaries, it was usually with the descriptor 'half-caste', always implying a lack of authority or authenticity. As a functionary of the Expedition - as a guide, translator or marine pilot - he was accepted and even taken for granted. But as someone of mixed race, he was of no use to Setzler's investigation of physical anthropology, presumably because Setzler also subscribed to his colleagues' notion of Arnhem Land being a Stone-Age society. As an ethnographic informant, Blitner was likewise seen as limited in value. In taking this course, the Expedition was turning its back on major discussions within anthropology. Since the interwar years, the desirability or otherwise of racial mixing had been a subject of theoretical and public interest. Racial purists were locked in debate with those who argued for the possible value of racial hybridity, especially in tropical environments. In 1926, the Harvard anthropologist Earnest A. Hooton had described miscegenation as 'perhaps the most important field of research in anthropology today' ${ }^{15}$ Hooton played a key role in initiating an earlier US-

\footnotetext{
11 Peter Worsley, who knew Blitner in the 1950s, confirms his proficiency in all these languages. Personal communication, 7 March 2010.

12 Frank M. Setzler, 1948, Diary kept on Arnhem Land Expedition, vol. 1, Papers of Frank Maryl Setzler, 1948-1973, MS 5230, NLA, p. 51.

13 Charles P. Mountford, 1948, Expedition to Arnhem Land, Personal Journal, vol. 1, p. 169, PRG 1218/17/12, Mountford-Sheard Collection, SLSA.

14 Ibid., pp. 188-9.

15 Cited in Anderson, W. 2009, 'Ambiguities of race: science on the reproductive frontier of Australia and the Pacific between the wars', Australian Historical Studies, vol. 40, no. 2, p. 151.
} 
Australian research venture, the Harvard-Adelaide expedition run jointly by Norman B. Tindale and Joseph Birdsell in 1938-39. As Warwick Anderson points out, this 'Half-Caste Survey' was specifically motivated by an interest in the health and adaptability of 'the growing numbers of people in Australia claiming mixed European and Aboriginal ancestry'. ${ }^{16}$

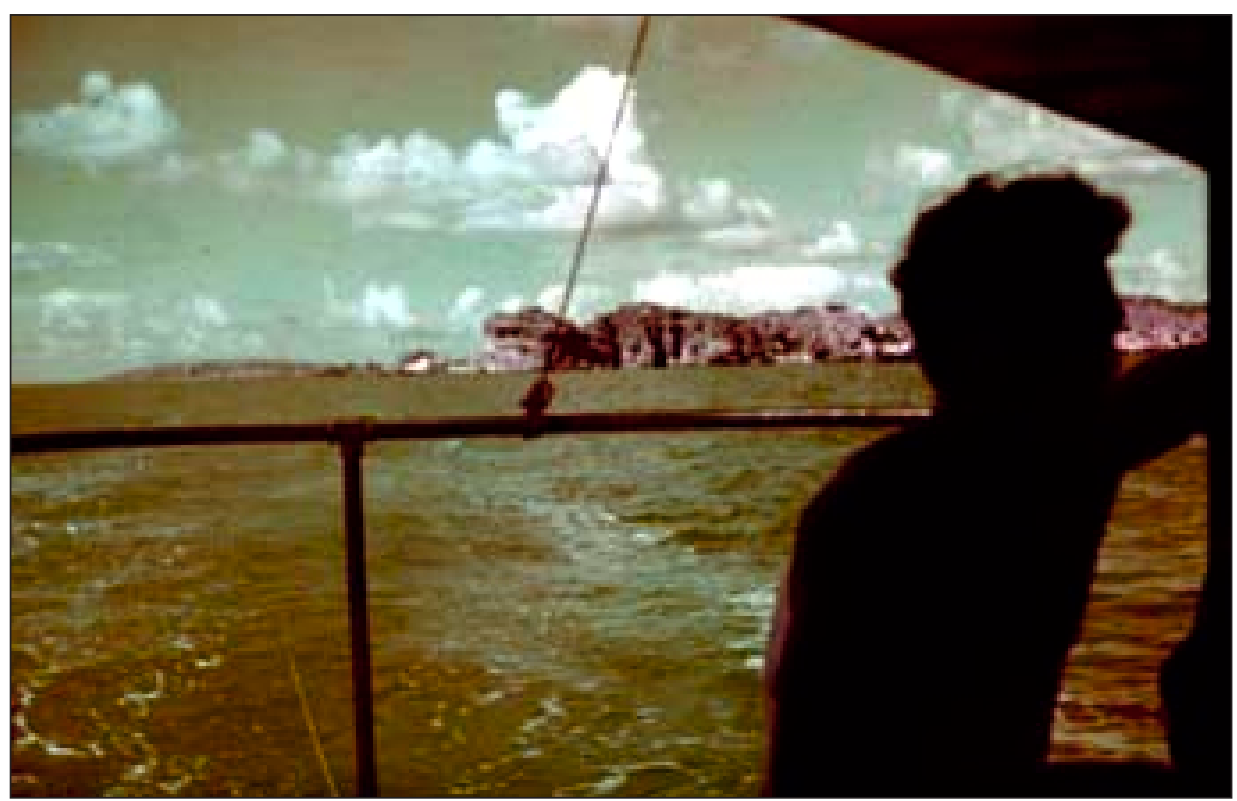

Figure 19.3 Portrait of Gerald Blitner, 1948

Photograph by Frank M. Setzler. By permission of National Anthropological Archives, Smithsonian Institution. Photo Lot 36, Box 8, No. 88.

The Arnhem Land Expedition anthropologists never explained their lack of interest in mixed-race people, but it is fully evident in their attitude to Blitner. Even as a photographic subject, he was generally avoided as a waste of film. Mountford in particular kept him well outside the frame. My heart sank when, after the interview, I showed Gerry the 1949 National Geographic article on the Expedition, written by Mountford. ${ }^{17}$ Given all he had done to support it, he expected to find a photo of himself. There was none, and his disappointment was palpable. Nor did he appear in Howell Walker's article on the Umbakumba settlement published four years later. Frank Setzler took just one photo of Gerry, which I found at the Smithsonian Institution: the final negative in a series of 88 that Setzler took on Groote. Even the numbering suggests that this was an afterthought. Unusually for Setzler, who was a more than competent

16 Ibid., p. 153.

17 Mountford, C. P. 1949, 'Exploring Stone Age Arnhem Land', National Geographic magazine, vol. 96, no. 6. 
operator of his view camera, the photograph is technically poor, despite being a well thought-out composition. The challenge of photographing dark skin in harsh daylight is known to anyone who has used a camera in Arnhem Land. Setzler's task was made that much more difficult by the fact that Gerry was seated in the shade of the sail, which had the effect of heightening the contrast between him and the glare upon the water. The resulting image acquires what I suppose is an accidental symbolism: a darkening of Gerry to the point that his identity is obscured. Setzler must have rated the image a failure, for the negative was neither printed nor selected for inclusion in the set of lantern slides that he afterwards used in illustrated lectures. When asked about Gerry, Raymond Specht fondly described him as 'a power of strength' to Fred Gray and the Expedition members. ${ }^{18}$ Yet in the visual record, he hovers at the edge of invisibility.

The Arnhem Land Expedition's absorption of racial ideology is never more explicit than in its treatment of Gerald Blitner. From the age of four, when, to the horror of his mother, he was catapulted into his new existence on the island, Gerry's mixed parentage had directed the course of his life. His marginality, his invisibility, his alleged 'unreliability' in the opinion of Mountford and others, must have been apparent to him, and I wonder whether his tendency to put himself centre stage in every story he told was not in some way an after-the-fact bid for compensation for the way his supposed racial hybridity had pushed him out of the picture in his dealings with the Expedition, as it did on countless other occasions during his life. People of mixed race were often portrayed as 'lost between two worlds', but this in no way approximated Blitner's experience or self-perception. For him, having mixed heritage was more like a form of dual nationality - an asset rather than a hindrance. According to his world view, it added to his authority as a worker and thinker. Since his was a knowledge rooted in two worlds, he had a greater pool of collective wisdom from which to draw. An altercation with incompetents in the air force that occurred during construction of a landing strip on the island illustrates the point:

They couldn't even nail fibro. I said, 'Hey, stop doing that.' I went and told the superintendent, 'I'm the foreman of the - of the works. Tell 'em not to put anything anymore until I do it'...I said, 'This is the expert, Black Fella. Learn from two societies. Take it all off or get off the job.'

Gerry's linguistic talents, combined with building and carpentry skills, some mechanical know-how, and his willingness to work in almost any capacity, must have made him attractive to Fred Gray as a prospective employee. He never mentioned what year it was that he moved from the west coast to Umbakumba, but I suspect it was 1947. Superintendent Gray had been at him for years to come to work for him, and finally he accepted the offer. During the war, he had

18 Raymond Specht, Personal communication, 5 September 2007. 
started working for the Royal Australian Air Force, and had taken up residence in military barracks. This marked his definitive break with the mission. He got out, he explained, because while he lived on mission premises his pay was kept in its entirety by the CMS. Economic independence was for Gerry a driving force, and that too can be connected with the sense of empowerment he drew from his white heritage.

Fred Gray (1899-1995) was a native of Worcestershire who migrated to Australia in his mid-twenties. Having lived mainly in the Gulf Country since 1932, he was, by 1948, considered a veteran of the region. An interest in trepanging brought him to coastal Arnhem Land where he developed a network of contacts with the local clans. Gray was close to several episodes of frontier violence in 1932, beginning at Caledon Bay, where five Japanese fishermen were fatally speared. The subsequent slaying of a sergeant on Woodah Island, and the deaths about this time of two imprudent sightseers in an unrelated incident, prompted media hysteria about murderous savages. Gray was involved in bringing the Yolngu elders Dhakiar and Merarra and three other men who admitted involvement in the violence to Darwin where they faced the justice system (a term I use loosely). ${ }^{19}$ Gray's involvement in the incident greatly raised his profile with the Department of Native Affairs and the Northern Territory administration. The goodwill he won at that time would serve him in later years as he developed the settlement at Umbakumba.

Gray had visited Umbakumba, with its extensive lagoon, in the mid-1930s to harvest the sea slug known as trepang. In 1938, the Department of Civil Aviation identified it as an appropriate location for flying boats to land and refuel; 2832 ha were revoked from the Arnhem Land reserve and the construction of fuel tanks, a weather station and associated infrastructure commenced. Gray found employment organising an Aboriginal work force that numbered about 200. Construction ended, but the population that had built up at Umbakumba remained - and so did Gray. At what point he adopted the title 'superintendent' (a word favoured in missionary as well as asylum, prison and police circles) is difficult to tell, but as a white man among Aborigines he naturally saw himself in a position of leadership. By establishing gardens and bringing goats to the island, he maintained a trickle of income through the sale of meat and vegetables to the personnel who manned the Qantas base, among them Frederick Rose, a meteorologist, fervent communist and British-trained anthropologist, with whom Gray was friends for some years.

19 There are several accounts of the Caledon Bay killings. Examples include: Egan, E. 1996, A Justice All Their Own: The Caledon Bay and Woodah Island killings 1932-1933, Melbourne University Press, Carlton South, Vic.; Dewar, M. 1992, The 'Black War' in Arnhem Land: Missionaries and the Yolngu 1908-1940, the Australian National University North Australian Research Unit, Darwin; and McMillan, A. 2001, An Intruder's Guide to East Arnhem Land, Duffy \& Snellgrove, Sydney, ch. 6. The 2004 film Dhakiyarr vs the King (dir. Tom 
Before the war, Rose had been stationed at Umbakumba as a meteorologist and in his spare time he did a foundational study of Groote Eylandt kinship. He returned to the settlement with the Expedition party and stayed for some weeks, helping set up the anthropological research. Qantas services had been disbanded after the outbreak of the Pacific War, and the Umbakumba base was never again used for commercial aviation. Gray had remained at Umbakumba throughout the vicissitudes of the war years. He did not volunteer for military service, and instead carved out for himself a unique position on the island. Gerry cast Gray as an authoritarian figure whose offers of employment he had long resisted, partly because of reported violence on the settlement.

I liked him but I still didn't like his-lot of his ways, like beating, molesting Black Fellas sometimes.

Q. What do you mean molesting them?

A. Belting them, hitting them with sticks just for the fun because he's a white man.

Gerry, who seemed to dislike speaking ill of anyone, had an ambivalent attitude to Gray, who by the time of his death at the age of ninety-five had become an iconic figure in the Northern Territory. He received the Order of Australia for his 'services to Aboriginal people'. ${ }^{20}$ Amidst the memories of violence and disagreements, some sentimental feelings must have lingered, for a photograph of the two of them, taken years later at Gray's house outside Darwin, hung on Gerry's wall. He - and I gather most Aboriginal people on the island-addressed Gray as 'Dad', and sometimes Gerry referred to him as such in the interview. The familial language must to some extent have been modelled on the web of kinship affiliations indigenous to the island. Yet it also expressed his status as a patriarch. Gray's rule of the settlement was oppressive; Fred Rose later commented that 'Gray was no philanthropist and to implement his schemes he exploited the Aborigines', especially their ignorance of money. ${ }^{21}$ Gerry would have agreed with this, and it is little wonder that he lasted only a few years in Gray's employ. Mountford's wife, Bessie, the Expedition secretary, expressed in her diary their collective bewilderment at the economic foundation of the settlement: 'Whence the finance we know not. ${ }^{22}$ But by careful if surreptitious observation, Gerry had figured it out. The income largely comprised revenue Gray received from the child endowment, a Commonwealth payment introduced in 1943 ostensibly for the purpose of supporting and strengthening the family unit. When the benefit was extended to the Aboriginal population, Gray exploited a loophole in the system that he might have learned about from the CMS missionaries who

\footnotetext{
20 Dewar, M. 1995, 'Fred Gray', (Obituary), The Australian, 4 August 1995.

21 Rose, Australia Revisited, p. 133.

22 Bessie Mountford, 1948, Arnhem Land Expedition Diary, vol. 1, Bessie Mountford Papers, p. 90, PRG $487 / 1 / 1$, SLSA.
} 
also made full use of it. This was a provision in the legislation that allowed any institution that kept children in dormitories to receive the child-endowment money and use it for their own ends. Gray - or rather his Aboriginal labourers built dormitories where the children were compelled to sleep. As custodian, he could legitimately claim the allowance. Parents camped nearby to be close to the children and some took up work in the gardens. Gray was able to claim success in his civilising project on several fronts. He advertised the fact that thanks to his settlement, these former nomads were abandoning their wandering ways. ${ }^{23}$ He explained to Bessie Mountford that the separation of children from their parents was justified because it gave him leverage in breaking up the tradition of polygamy on the island, where young brides were monopolised by older men. ${ }^{24}$ The settlement numbered 163 inhabitants when the Expedition arrived. ${ }^{25}$

The constant pressure to demonstrate the usefulness of the settlement, and the lingering suspicion that a single white man in his position was on the lookout for sexual opportunities, might have contributed to his decision to propose by telegram to Marjorie Southwick, a schoolteacher he had known in England but had not seen for more than 20 years. Her decision to migrate from the south of England to marry Fred, and live with him on Groote Eylandt, is less explicable. In her memoir, Life with the Aborigines (1986), Marjorie said that she had always known that 'Fred was the only man for me'. ${ }^{26}$ Bessie Mountford, whose diary best registered the emotional pulse of the Expedition, makes it plain, however, that Marjorie was abysmally unhappy. (Although they never divorced, Marjorie eventually returned to England and lived separately from Fred.) The bizarre world she had come to, and which she was keen to exit as soon as possible despite her affection for the Umbakumba residents, is apparent in film footage of the settlement, shot by Howell Walker. ${ }^{27}$ Gray's propensity to unnerve the pen-pushers at Native Affairs is evident here in all its glory. Not for him the pith helmets and safari suits worn by Mountford and the likes. Rather than barrier himself against the tropics, Gray pared down his wardrobe to almost nothing. A loincloth or naga naga, as it is known in Aboriginal English, was his sole apparel. He wore it daily, as Gerry told me while we watched footage of Gray supervising a boxing match between two boys from the dormitory. As an agent of 'civilisation', Gray was at best unpredictable. He had a taste for music, and entertained the expeditioners with sessions around the gramophone, listening to his collection of classical discs. Yet these accoutrements of refinement never quite dispelled the bureaucratic suspicion that Frederick Gray had 'gone native'.

23 Gray's promotion of the settlement is apparent in Walker, H. 1953, 'From spear to hoe on Groote Eylandt', National Geographic Magazine, vol. 103, no. 1.

24 Bessie Mountford, 1948 Arnhem Land Expedition Diary, vol. 1, pp. 88-9, PRG 487/1/1, SLSA.

25 Cole, Fred Gray of Umbakumba, p. 99.

26 Gray, M. 1986, Life with the Aborigines, Regency Press, London, p. 9.

27 Walker, H. [as cine-photographer] 1950, Aboriginal Australia, (Lecture film), National Geographic Society, Washington, DC. 


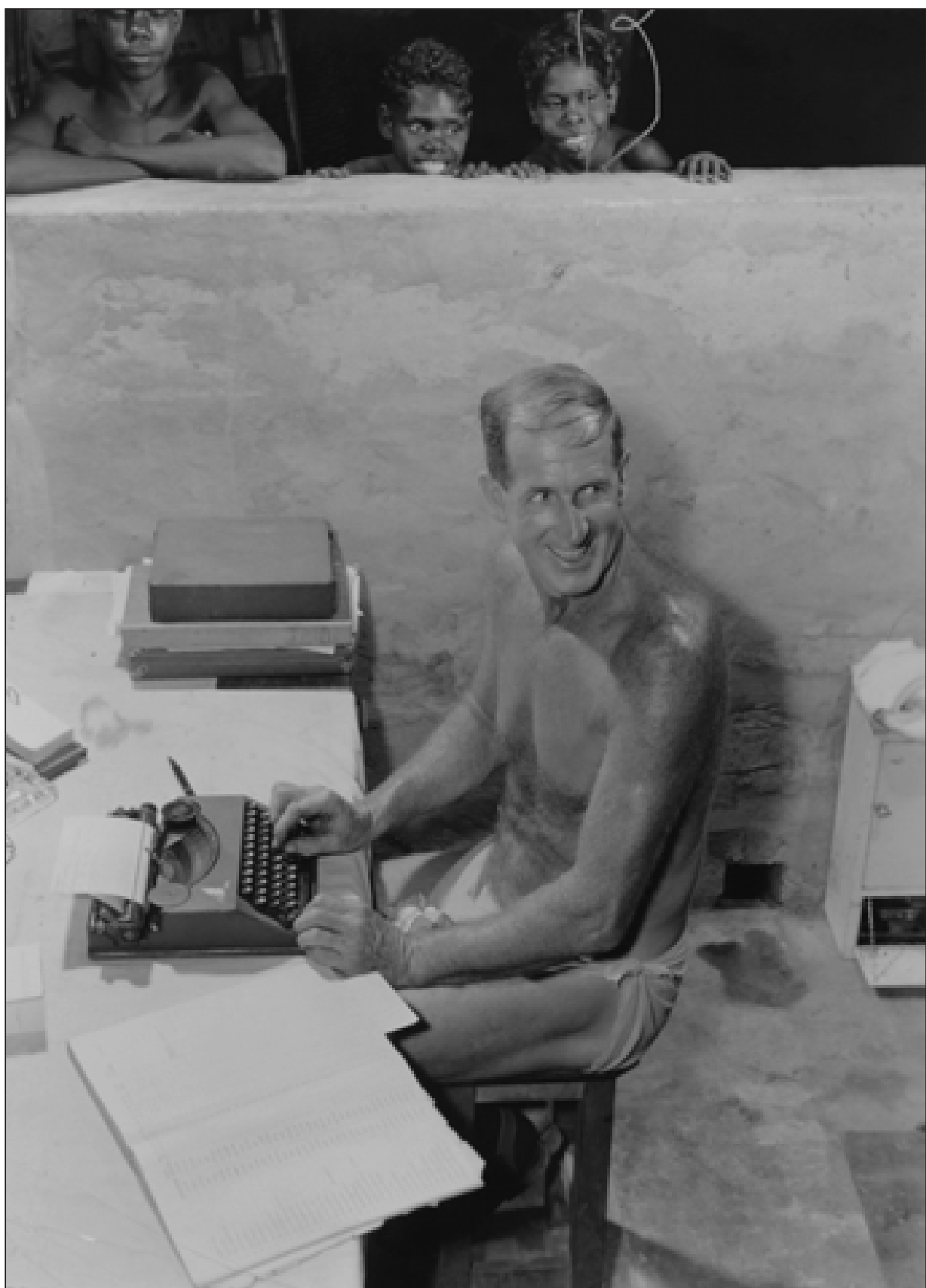

Figure 19.4 Fred Gray at Umbakumba, 1948

Photograph by Howell Walker. By permission of National Geographic Stock 
Gerry claimed that the impending arrival of the Expedition was the reason Gray renewed pressure on him to come to work at Umbakumba. Knowing that the settlement would be under the spotlight, a makeover seemed appropriate. Gray had recently acquired a six-cylinder engine suitable for pumping water, and, with Gerry's energetic input and ability to mobilise the Umbakumba community, the gardens were greatly expanded to cover about 5 ha. 'The Mountford mob just come in at the right time,' he explained. The garden was flourishing and the whole place shipshape. Under Marjorie's tutelage, an enlarged school choir was ready to entertain the visitors. Gerry beamed proudly when he told of Mountford's effusive praise for the set-up. He said he regarded it as the best Aboriginal settlement he had ever seen. Privately, however, Mountford must have been reeling at this conspicuous display of 'civilisation', which McCarthy and others immediately identified as a failure in his planning. Landed in this imbroglio, the Expedition's three ethnological researchers pursued lines of inquiry that took them as far as possible from the queer spectacle that was Umbakumba. In the mode of physical anthropologist, Setzler searched for bones and other markers of racial uniqueness; McCarthy hunted for ancient rock art; and Mountford collected totemic symbols in the form of bark paintings and studied music and ceremony that seemed safely quarantined from historical influence.

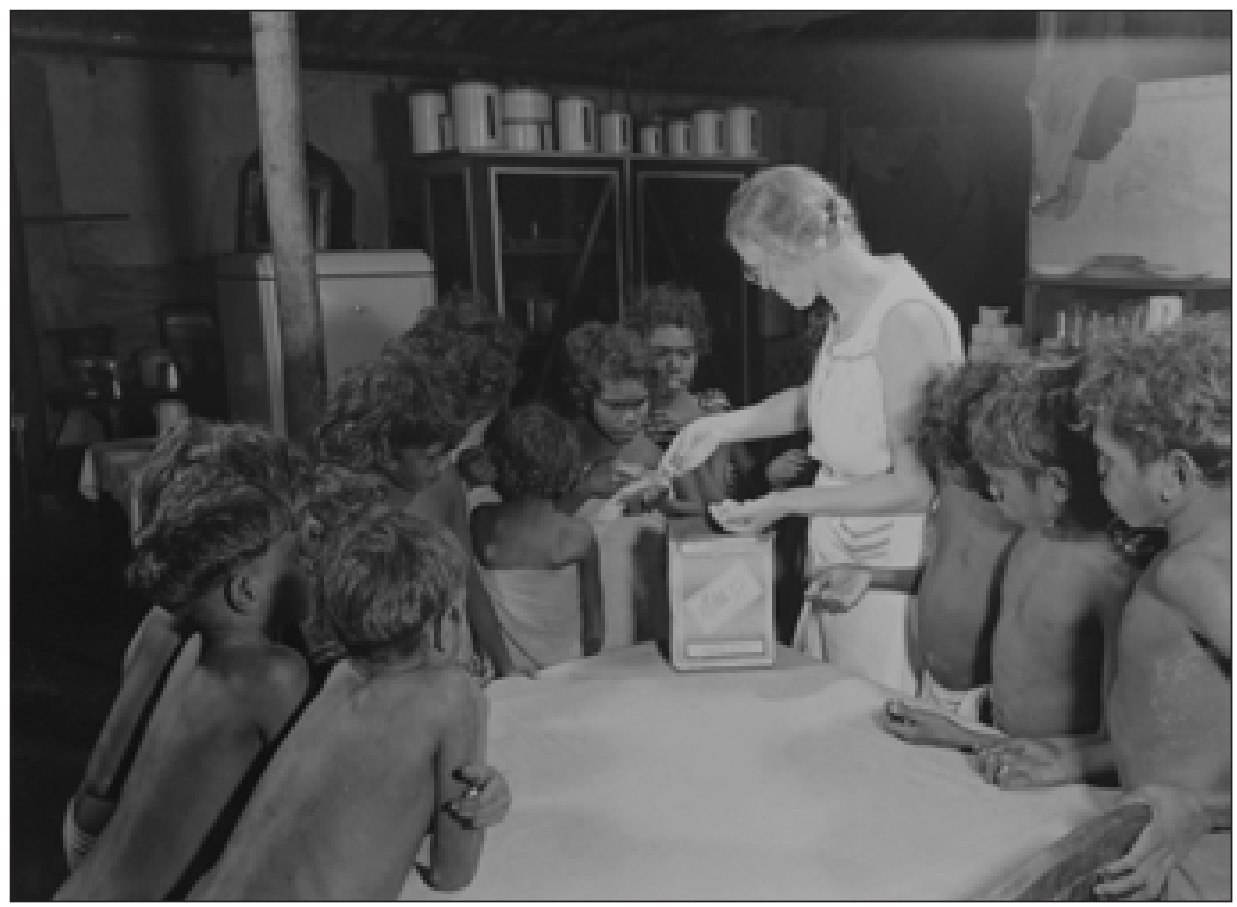

Figure 19.5 Marjorie Gray distributing food to children at Umbakumba, 1948

Photograph by Howell Walker. By permission of National Geographic Stock. 
The role Gerry created for himself during the Expedition went far beyond his many acts of practical assistance. He became the unofficial go-between - a position that involved translation in the linguistic sense, and more. As we know from McCarthy, there were others at Umbakumba who spoke English, but most of them were young. The older people, who were most learned in law and culture, were the ones of greatest interest to the researchers. Gerry served as a conduit, moving back and forth between the scientists and the locals, articulating requests and delivering responses. He was party to both sides of the negotiations. His position is best thought of as a cultural broker or intermediary. The term 'cultural broker', which gained currency among North American historians in the 1990s, refers to a kind of specialist that emerged in nearly all situations of colonial contact and occupation. Motivated by necessity or opportunism - or frequently a combination of the two-cultural brokers played a central role in the two-way transmission of languages, ideas and commodities during the upheaval and confusion of the frontier experience. As the historian Margaret Connell Szasz explains it, cultural brokers devised ways of penetrating the borders between disparate peoples. Finding porosity in these boundaries, they forged 'pathways that link peoples rather than barriers that separate them'.$^{28}$ Trade, translation and diplomacy are among the roles assumed by such people. Szasz says of them:

Of necessity, their lives reflected a complexity unknown to those living within the confines of a single culture. They knew how the 'other side' thought and behaved, and they responded accordingly. Their grasp of different perspectives led all sides to value them, although not all may have trusted them. Often they walked through a network of interconnections where they alone brought some understanding among disparate peoples. These mediators, therefore, have held a distinctive position in our past and into the present. ${ }^{29}$

The role of Gerry and other cultural brokers threw into question many of the claims to 'discovery' that were axiomatic to this large-scale scientific venture. For this and other reasons (including, in Gerry's case, his skin colour), their contributions are submerged to the extent that they are largely undetectable in official narratives such as the four-volume report on the Expedition. There is, however, sufficient evidence in other sources to build something of a picture of the young men who assumed roles of cultural brokerage in 1948. The social organisation of Arnhem Land is deeply gendered. The young men's age and gender were consistent with customary practice for dealing with visitors. Traditionally, it was the role of younger men to come forth as emissaries, negotiate

28 Szasz, M. C. 1994, 'Introduction', in M. C. Szasz (ed.), Between Indian and White Worlds: The cultural broker, University of Oklahoma Press, Norman, p. 3.

29 Ibid., p. 6. 
with strangers, and report back to the senior men who wielded serious power. In 1948, the tendency towards male-to-male interaction, especially in the early meetings, was consolidated by the imbalance of the sexes within the Expedition party (representing as it did another highly gendered society). ${ }^{30}$ Bessie Mountford, the honorary secretary, and nutritionist Margaret McArthur were the only women on a team that ultimately involved 17 researchers and support staff. The likelihood that younger Aboriginal men would assume positions as negotiators was increased by the widely variant education and life experience of mission residents in the immediate postwar era. The intergenerational mix included older people born and educated in the bush and younger folk schooled in English by missionaries or, at Umbakumba, by the Grays. Almost inevitably, young men made the opening gambits. In so doing, they were required to tread delicately around the factions and kin-based affiliations extant in their own communities. These are unlikely ever to have been straightforward, and in the mission era they were greatly complicated because a medley of sometimes rival clans, many of them bearing the grief of separation from their ancestral country, were concentrated together. This all added to the strain, indignity and confusion of negotiating the rules and expectations of Balanda (as white people are known throughout Arnhem Land).

In scenarios so fraught and complex, it stands to reason that the brokering of a successful relationship with the Expedition could enhance the status of the negotiator or of sectional interests with whom he was aligned. For Gerald Blitner, a relative newcomer to Umbakumba, the Expedition represented a considerable opportunity to consolidate his position within a settlement where he was still something of an outsider. The extent to which his skin colour marked him as different among the Umbakumba people is something I would have liked to ask about, but I never found a tactful way of phrasing the question. At times he spoke of being a 'yella fella' — a sometimes derogatory term in Aboriginal English. So I can only assume that he did at times experience a degree of discrimination from the Aboriginal side. His situation was thus very different to that of Wandjuk Marika, who performed an equivalent role when the Expedition was at Yirrkala. Wandjuk (1936-87) was the son of the esteemed artist and Rirratjingu clan leader Mawalan Marika. By dint of birth, he could expect a central place in the cultural and political life of Yirrkala - a position he certainly attained. ${ }^{31}$ His closeness to the Expedition no doubt played a role in his family's high level of representation in the paintings collected and ceremonies performed during the Yirrkala sojourn of the Arnhem Land Expedition.

30 For discussion of gender and the Expedition, and the role of nutritionist Margaret McArthur within it, see Clarke, A. 1998, 'Engendered fields: the language of the 1948 American-Australian Expedition to Arnhem Land', in M. Casey, D. Donlon, J. Hope and S. Wellfare (eds), Redefining Archaeology: Feminist perspectives, ANH Publications, Research School of Pacific and Asian Studies, the Australian National University, Canberra. 31 See Marika, W. 1995, Wandjuk Marika: Life story as told to Jennifer Isaacs, University of Queensland Press, St Lucia. 
For all the communities involved, the Expedition was both an opportunity and an imposition. The high level of cooperation it received makes little sense unless we grasp this prickly paradox. For the Arnhem Landers, the Expedition brought economic wealth: an influx of tobacco, trade goods, and a certain amount of cash. The economic reality of the Expedition, and the alternative it provided to the mission economies where tobacco and food supply were linked to church attendance and other disciplinary measures, explains much about the receptiveness of Arnhem Landers to the Expedition and the dislike of it on the part of missionaries. ${ }^{32}$ Moreover, the Expedition provided occasion to study the ways of Balanda. This cannot be underrated, for at that postwar moment in Arnhem Land history, the need to come to grips with white Australia, and to convince it of the legitimacy of Aboriginal ways, was becoming ever more apparent. It is highly significant that later in their lives both Blitner and Marika entered the national stage as advocates for Aboriginal rights. Blitner served as deputy chairman of the Northern Land Council for 18 years, and was chairman from 1980 to 1983. In this, he built upon other experiences of cultural brokerage, including a period on Groote as an employee of the mining company GEMCO where he liaised between company officials and traditional owners. ${ }^{33}$ Wandjuk attained distinction as an artist, musician, lawman and cultural ambassador. He was a founding member of the Aboriginal Arts Board of the Australia Council for the Arts and travelled internationally for festival and conference engagements. A great spokesman for his people, he was a bitter opponent of bauxite mining on the Gove Peninsula and contributed to that famed protest, the Bark Petition of 1963. To suggest that lessons from the Expedition, alongside many other interactions with Balanda, helped in formulating the ideas, the personal styles and political agendas of both these men is not being overly adventurous. To be efficacious, their campaigns for justice and recognition required knowledge of the society and political system that had long regarded them as Stone-Age curiosities.

There were members of the Expedition whom Gerry remembered with considerable fondness. He worked closely with the Smithsonian ichthyologist, Robert Miller, in developing his large collection of fish specimens from the island (see Miller and Cashner, this volume). The warmth between them is recorded in Miller's diary, recently acquired by the National Library of Australia, and is reflected in Miller's Kodachrome photographs. ${ }^{34}$ In these images, Gerry does not lurk in the shadows as he does in the Setzler portrait. We see him as a family man, pictured at Umbakumba beside his wife, Jessie (nee Huddlestone), whom he married in 1946, and their first-born, Donald.

\footnotetext{
32 The corporal punishments meted out at Emerald River Mission are described in Dewar, The 'Black War' in Arnhem Land, p. 34.

33 I am indebted to Campbell Macknight for sharing these memories of Blitner in the 1960s. Personal communication, 26 March 2010.

34 R. R. Miller, 1948, Arnhem Land Expedition Diary, Papers of Robert Rush Miller, 1947-1951, MS 10053, NLA.
} 


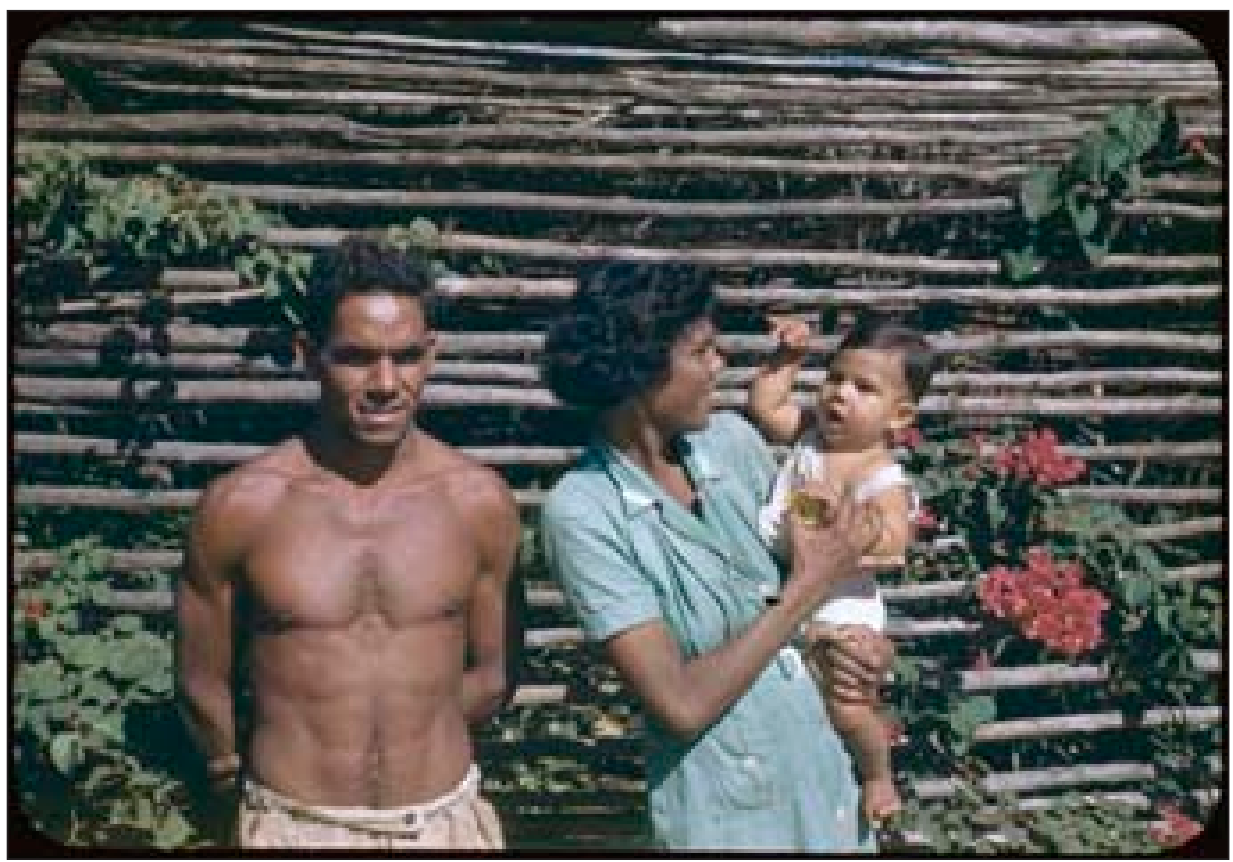

Figure 19.6 Gerald, Jessie and Donald Blitner at Umbakumba, Groote Eylandt, Northern Territory, 7 July 1948

Photograph by Robert Rush Miller. By permission of the National Library of Australia. PIC/12323/37.

Gerry's relationship with Mountford was not harmonious. He quickly became convinced that Mountford was personally hogging the resources of the settlement and the assistance of the Aboriginal people. To the frustration of the other members, he explained, Mountford 'was getting more trips than any other soul on board that expedition'. Gerry's alertness to rancour within the party is revealing, for it shows that the internal politics of the expeditioners were of interest and concern to the residents of Umbakumba, many of whom were forming their own relationships with particular researchers and who did not expect to be monopolised by just one of the visiting party. Blitner described an altercation involving Setzler and Miller, who complained to Mountford about the allocation of resources:

'We want more freedom with the boat and the use of Mr Blitner and some Aboriginals and we wanna see some of the islands too.' So I went and spoke to him [Mountford]. 'Dr Setzler and Miller and some English guys, doctors, it's their turn to go out and see something.' So I gave him merry hell, I gave Mountford merry hell, you know... I worked for those Americans - no, I mean I gave them more. I gave them more than I gave Mountford. 
Gerry's admission that he tried to help other researchers more than Mountford suggests that ructions within the Expedition party were affecting the decision making of the Aboriginal hosts - and consequently influencing the path that the research was taking. Unlike the natural-history researchers, each of whom worked in his own clearly defined area of expertise, the crossover of interests among the three ethnological researchers made their situation on the island much more fraught. ${ }^{35}$ Setzler and McCarthy fell into a sometimes uneasy alignment, while Mountford and McCarthy developed a hostility that lasted until the end of their lives. The stranding on a reef of the Phoenix, the dilapidated barge chartered to freight the supplies and equipment from Darwin to Groote, put strain on Gray with so many extra mouths to feed. As Gray's 'right hand man', Gerry was fully cognisant of the pressure it put on the community's resourcesand on Gray's relationship with Mountford. On this matter, Gerry seems to have sided with Gray, whose feelings towards Mountford are made plain in his parting gift to the Expedition: an invoice for $£ 307$ for 'employment of Natives' during their time on the island. This could be read as a grab for cash on Gray's part, though it was also calculated to air his grievances. A memorandum accompanied the invoice, complaining that the 'deployment of natives to the Expedition completely upset the economy of this Settlement' ${ }^{36}$

As newcomers to Arnhem Land, the ethnographic researchers tried to compensate for their lack of reference points within the local society. They sought help from the likes of Gray, Rose and Bill Harney who were more experienced than themselves, and they did their homework by reading the work of other scholars or travellers. The precedents set by earlier researchers greatly affected the perceptions of the visiting party. As much as the ethnologists were searching for 'new' data, the direction of their inquiries was profoundly influenced by earlier investigations. As a long-term associate of the South Australian Museum, Mountford had had plenty of time to study the writings and material culture collections of Norman Tindale, who worked on Groote in the early 1920 s. ${ }^{37}$ Gerry himself raised an intriguing example of this when we discussed Mountford's interest in secret-sacred ceremony. To paraphrase Gerry's position, he cast Mountford as something of a bull in a china shop in his approach. Gerry was deeply unnerved when Mountford listed a number of ceremonies that he hoped to witness during his residence on the island:

\footnotetext{
35 See May, S. K. 2010, Collecting Cultures: Myth, politics, and collaboration in the 1948 Arnhem Land Expedition, Altamira Press, Walnut Creek, Calif.

36 Invoice from F. H. Gray to Arnhem Land Expedition, 8 July 1948, AASEAL Correspondence, Volume 5, March-July 1948, Mountford-Sheard Papers, PRG 1218/17/8, SLSA.

37 Tindale, N. B. 1925-26 and 1928, 'Natives of Groote Eylandt and of the west coast of the Gulf of Carpentaria', parts I and II in Records of the South Australian Museum, vol. 3; part III in Transactions of the Royal Society of South Australia, vol. 53.
} 
I couldn't stand some of the stuff what Mountford kept on trying to initiate, you know, to make go. But he was after sacred things, very sacred: the Kunapipi, the Yabuduruwa, Lorrkon, Lilki, all those different dances, that we call 'em.

Q. He wanted to make photos and things of them?

A. Well, he wanted to make photos and things... And I said, 'You have to be very careful because these are not - not play dance, this is - this is the Kunapipi, you know. You must appreciate the Aboriginal sense of it all and bear holiness.

The revelation that Mountford asked to see these ceremonies struck me as odd. The rites mentioned are indigenous to the mainland, not to Groote Eylandt. Kunapipi, for example, is the large ceremony of male initiation, dedicated to the Rainbow Serpent, that spread widely across the Top End during the twentieth century, though even to this day it has never been held on Groote. When I probed Gerry about Mountford's wish list, he explained that it originated from a book by an American. The name of the author he had not thought about for years, and he first gave it as 'Walker', but then acknowledged it was wrong. Our discussions of Howell Walker had put him off the scent, though not by much. The American he was thinking of was not Walker, but Warner-as he quickly confirmed when I put forth the name. Despite the initial mix-up, it struck me as a rather stunning example of Gerry's attentiveness to the goings on of the Expedition and to the retentiveness of his memory. The diaries of Mountford, Setzler and McCarthy confirm that they each had a copy of A Black Civilization (1937) by W. Lloyd Warner. This classic monograph was based on fieldwork with the community known to Warner as the Murngin of North-East Arnhem Land. As the author of the most substantial ethnography so far published on Aboriginal life in the region, Warner was very much on their minds (see Hamby, this volume). Setzler had taken the trouble to visit him in Chicago prior to travelling to Australia. Not only did Gerry reveal that Mountford's reading of Warner was influencing the sort of data he hoped to film or in other ways document, he revealed that people on the island were comparing the approaches taken by the two researchers. Mountford, he said,

thought he gonna get stuff like that, while Warner was doing things very quietly, you know, with man to man, but Mountford wanna be very, very abrupt and the man. He wanted to be the man: to find this, to give Australia that, you know, and I kept on talkin', 'Maybe you're tryin' to go too far.'

The proposition that Warner's methods were known and discussed on Groote Eylandt is not necessarily far fetched. As we know from the example of 
anthropologist and photographer Donald Thomson, researchers who lived among Arnhem Land communities for sustained periods became the subject of rich oral traditions. The twentieth century had seen the migration of mainland people, many from the Rose River region, to the western side of the island, and with them they brought a complex of ceremonies, one of which Mountford would eventually witness and document.

Gathering stories associated with sacred rock formations and other features of the landscape was high on Mountford's agenda. The eagerness with which he inquired into these subjects proved disconcerting to many of the men with whom he travelled around the island. Gerry remembered Banjo Nakwarrba, a senior man who dealt extensively with the researchers, being particularly aggravated at his persistence. He remembered Nakwarrba saying, " By golly, you know, this fella, he wants to know about every jolly thing. We might as well make fib ones stickin' up in the air too, you know."' But Gerry counselled against outright fabrication:

'Well, I don't want to bully you mob. I don't want to bully the conversation here but you give him what you want him to know andbut don't tell him a lie, you know. It's - it's better to tell him a bit of the truth than a lie,' and they said, 'Yeah, you're right.'

In his manner and technique, Mountford created for himself some significant obstacles that had to be overcome in his quest to witness and document a major ceremony. The ritual life of Arnhem Land was for Mountford a subject of the highest interest. He was aware of the importance of ritual to social structure and cohesion, and to the maintenance of relationships between the people of today and the ancestral beings. He also knew from his experiences in Central Australia and elsewhere that ceremony was among the most dramatic aspects of Aboriginal culture. Mountford had attained elevation and celebrity within his own society through his adeptness in channelling Aboriginal content into the iconography of white Australia. Ritual, with its superb combination of dance and body painting, and its frequent use of sculptural objects, had particular cachet in this regard. The resulting imagery was as distinctively Aboriginal as you could get. Needless to say, it was highly photogenic (as long as it occurred in daylight hours). The musical dimension was also crucial, and Mountford, with a newfangled wire recorder as part of his kit, was well placed to capture technologically this ultimate signifier of a 'primitive' culture.

Given what Gerry said about Mountford's tactless and rather intrusive style, it is interesting that any ceremony was held at all. But after extensive negotiations, involving consultation with senior knowledge holders based at Rose River, the decision was made to hold an extended men's ceremony on the east coast of Groote Eylandt to which male members of the Expedition would be privy. 
Mountford referred to it as the 'Arawaltja' and described it at length in Volume 1 of the Expedition records. ${ }^{38}$ Gerry did not use this name for the ceremony, but he knew it well. At its heart is a beautiful sequence of dances that pays homage to the sea creatures that are totems to the major clans. Peter Worsley, who in 1957 published a highly critical assessment of Mountford's ethnography in $M A N$, has identified the use of the term Arawaltja as symptomatic of 'amateurish' approach. The term auwarawalja (Worsley's spelling) is not the name of the ceremony but of the stringy-bark shelters that house sacred objects. ${ }^{39}$ Mountford would make a similar blunder at Oenpelli (now Gunbalanya), where he gave the secret-sacred name of a ritual object as the name of the ceremony, rather than its proper title, the Wubarr (see Garde, this volume).

Mountford mentions that the ceremony he witnessed was performed only by 'those aborigines who live on the western side of Groote Eylandt'. ${ }^{40}$ Blitner confirmed this when he watched the Expedition's footage of the ceremony on DVD. He said that he had first seen these dances when he was about fifteen and that the ritual had at that time been fairly recently introduced from the mainland by clans who had migrated there in recent generations. The performers of the ceremony were not the people of Umbakumba, with whom Mountford (according to Gerry) had rather burnt his bridges. Rather, visitors from the west of the island performed the 'Arawaltja' - much to the indignation of the locals, and to Gray as well. Mountford's diary records that Gray was 'somewhat opposed, because he is afraid of some old feuds breaking out afresh'. ${ }^{41}$ His apprehension turned out to be justified, for when the delegation of performers arrived at Umbakumba from the west to commence the ceremony, tensions in the Umbakumba community were high and an ugly fight erupted (see Jones, this volume). Mountford, at some risk to himself, managed to break it up. They were forced to shift the ceremony from the outskirts of Umbakumba to Thompsons Bay - about $13 \mathrm{~km}$ distant. So Mountford did get to view and document a major ceremonial cycle, but he achieved this only by taking advantage of pre-existing divisions between the clans who inhabited the island. Gerry claimed to have had extensive discussions with the men who performed the ceremony. They reported that one of the reasons they went ahead with it was that Mountford was emphatic that he had been permitted to watch comparable men's ceremonies in Central and other parts of Australia and that this entitled him to the same level of access in Arnhem Land. When I questioned Gerry about the men's preparedness to allow cameras and a sound recorder into this secret ritual, he

38 Mountford, C. P. (ed.) 1956, Records of the American-Australian Scientific Expedition to Arnhem Land. Volume 1: Art, myth and symbolism, Melbourne University Press, Carlton, Vic., pp. 22-60.

39 Worsley, P. 2008, An Academic Skating on Thin Ice, Berghahn Books, New York, p. 90. The book review is item 241 in MAN, vol. 57 (December 1957), p. 186.

40 Mountford, Records of the American-Australian Scientific Expedition to Arnhem Land, vol. 1, p. 23.

41 Charles P. Mountford, 1948, Expedition to Arnhem Land, Personal Journal, vol. 2, p. 395, PRG 1218/17/13, Mountford-Sheard Collection, SLSA. 
said that Mountford assured them that the documentation would be used only for research purposes and not shown publicly. If indeed Mountford made such a promise, he failed to keep it. Film and photographs of the Groote Eylandt ceremony were seen by men, women and children throughout the world. ${ }^{42}$

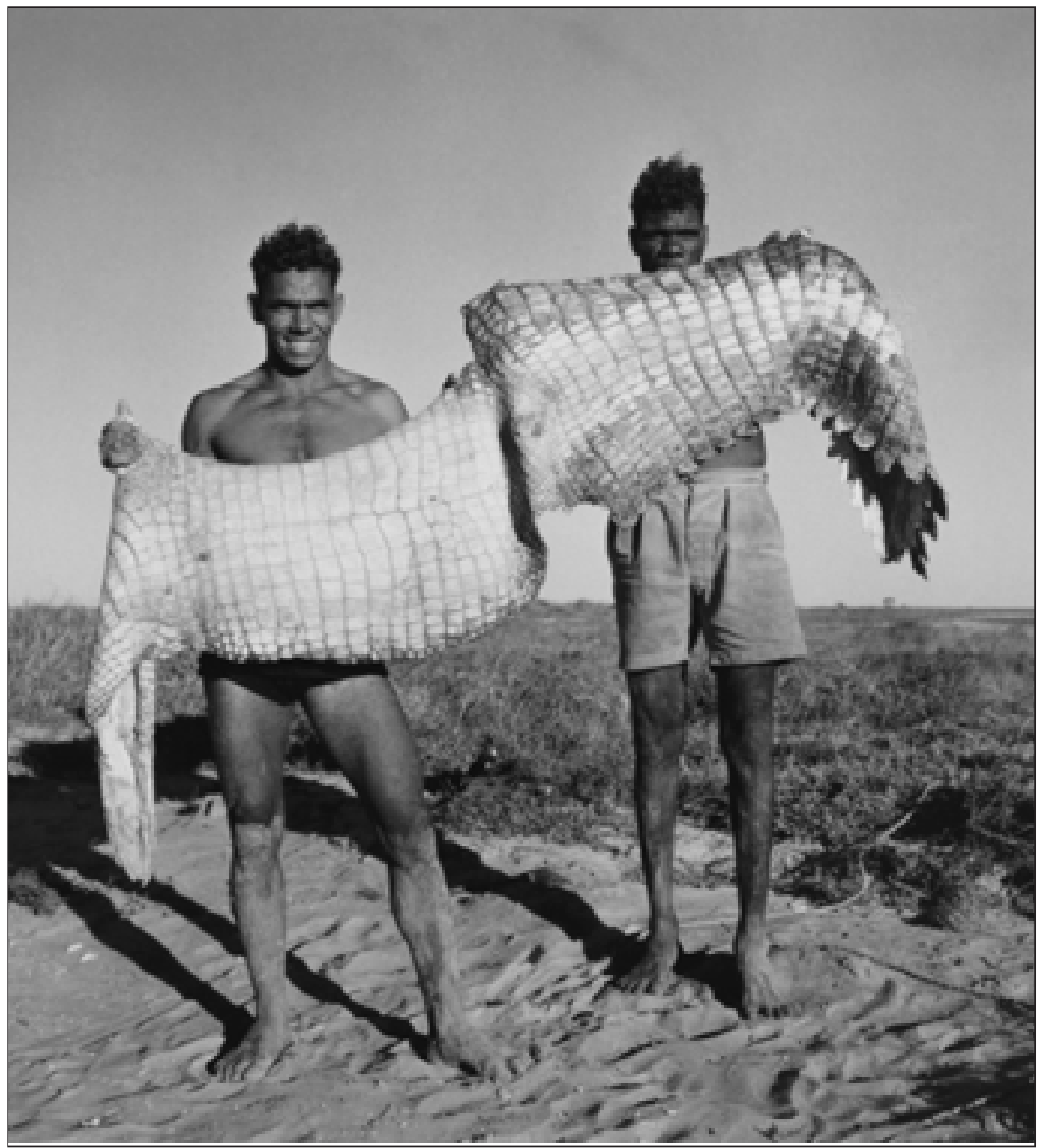

Figure 19.7 Gerald Blitner (left) and unidentified man with crocodile skin at Roper River, 1948

Photograph by Howell Walker. By permission of National Geographic Stock.

42 For further discussion of the documentation, see Thomas, M. 2007, 'Taking them back: archival media in Arnhem Land today', Cultural Studies Review, vol. 13, no. 2. 


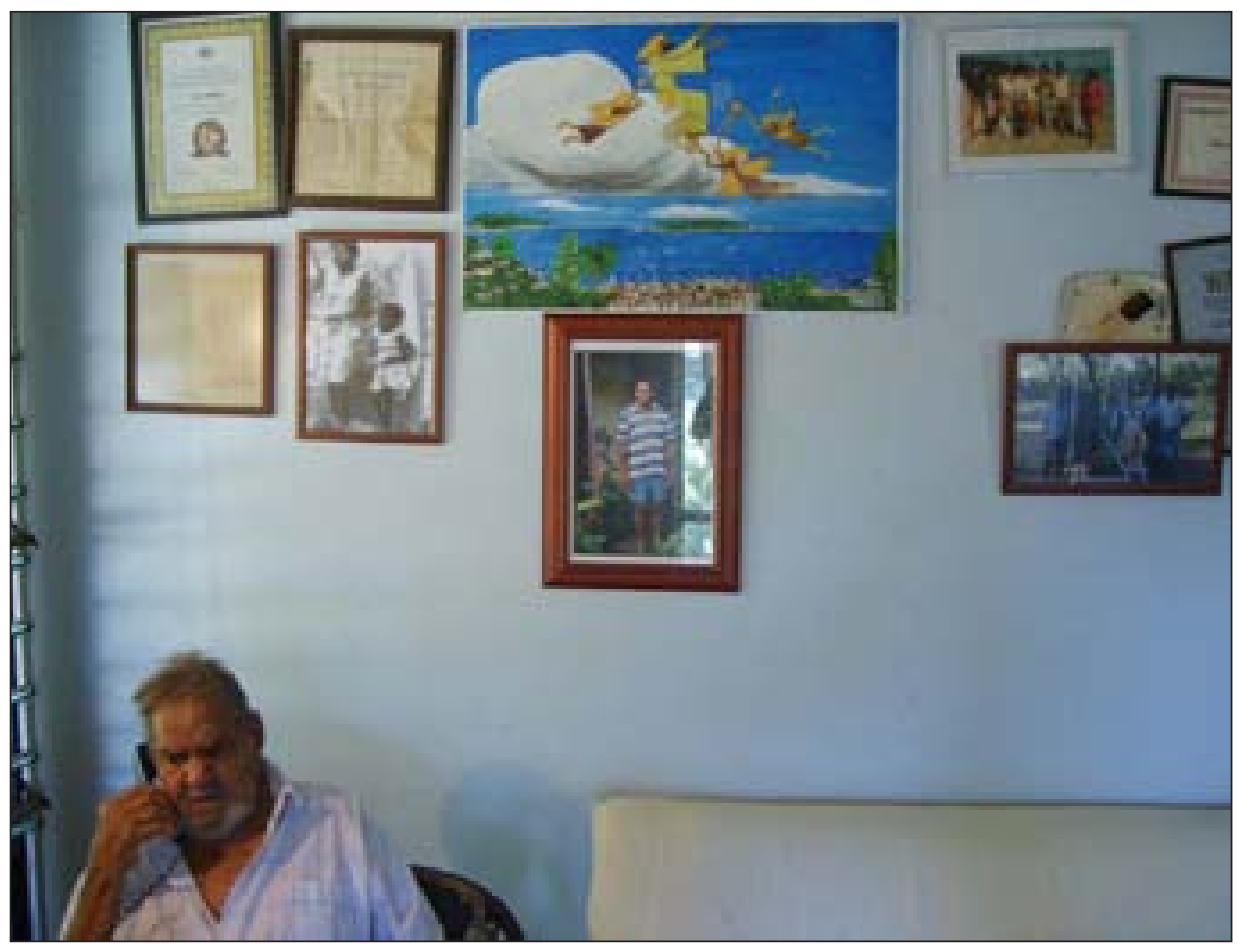

Figure 19.8 Gerald Blitner at home in Darwin, 2007

Photograph by Martin Thomas

Some four months after our interview, I was in Washington, DC, studying records of the Expedition at the Smithsonian. I had been there only a week when Sally May wrote with the sad news that Gerry had died in Darwin. It was February 2008. I heard that he was quickly flown to Groote and laid to rest on the island he loved. I was touched that his family, who did so much to encourage the interview going ahead, was anxious that I be advised of the news. With their support and permission, I have used their father's name publicly and reproduced these photographs of him.

Gerry's voice often came back to me during my time in Washington. I was thankful to think of him back on his island home, free of the pain and sickness of recent years. Even so, I yearned for a continuation of our conversation. How I would have loved to explore further the things we talked about, or to have shown him the beautiful black-and-white photographs taken by Howell Walker during their trip up the Roper, where Gerry's earliest years with his mother were spent. But such regrets - familiar to nearly all oral historians-by no means diminish the significance of Gerald Blitner's testimony. At the end of it all, he told me that he was deeply grateful he had done the interview, for he was 
himself surprised by the wealth of recollections it had prompted. The dialogue we enjoyed says much about the legacy of the Arnhem Land Expedition - still rippling and resonating 60 years later.

\section{Acknowledgments}

I am indebted to the family of Gerald Blitner for encouraging the interview and for allowing me to name and show photographs of their father in the wake of his passing. Thanks to Jon Altman, C. C. Macknight, Peter Worsley, Warwick Anderson, Rowena Dickins-Morrison, Amanda Harris and an anonymous peer reviewer for their comments on this chapter, and to Sally May for brokering the connection with Gerry. The interview was done as part of an Australian Museum Visiting Fellowship. The primary research in the United States was made possible by a Smithsonian Institution Fellowship. The National Geographic Society generously gave access to films, documents and photographs. 